\title{
EVALUATION OF AGRONOMIC AND SENSORY CHARACTERISTICS OF SWEET CORN HYBRIDS
}

\author{
Jelena Srdić ${ }^{1 \star}$, Marija Milašinović-Šeremešićn , Vojka Babić1, \\ Natalija Kravić́ ${ }^{1}$, Snežana Gošić-Dondo ${ }^{1}$
}

\begin{abstract}
Sweet corn is considered as tasty and quality food. Its kernels contain sugars that are in good balance with amino acids, minerals and vitamin $\mathrm{B}$. It is used as fresh product right after the harvest, but also for further industrial processing, freezing and canning. In breeding of sweet corn, equal attention is paid to the production of high and stable yielding hybrids, and to the enhancement of technological and sensory properties of the ear and kernel. The aim of this research was to establish agronomic and sensory properties of 12 sweet corn hybrids, 3 commercial and 9 experimental. The trial was set up according to the RCBD on two locations and in three replicates. The evaluation of agronomic parameters encompassed: fresh ear yield without husk, ear length, number of kernel rows and shelling percentage. Also, sensory characteristics were analyzed: appearance, color, smell, sweetness, juiciness, crispiness, pericarp hardness. Sensory characteristics were evaluated by voluntary panelists and scaled with $1-9$ point hedonic scale. Fresh ear yield significantly varied over locations and hybrids. The highest fresh ear yield had experimental hybrid ZP 481/1su - $13.33 \mathrm{t} \mathrm{ha}^{-1}$, while the lowest was $7.14 \mathrm{t} \mathrm{ha}^{-1}$ (ZP504su). The difference between sensory characteristics among hybrids was also noticed, although all hybrids had satisfactory sensory characteristics with the average sensory marks above 7.30/9.00. The best sweet corn hybrid according to sensory characteristics was ZP 483/1su (8.29), while the highest yielding one ZP 481/1su had an average sensory mark 7.70.
\end{abstract}

Key words: sweet corn, fresh ear yield, sensory characteristics

\section{Introduction}

Sweet corn is produced for human consumption for three main purposes i.e. fresh consumption, as frozen and canned products. Fresh consumption is timely limited because of fresh ears rapidly lose quality. Therefore harvest should be performed in the appropriate time 20-25 days after silking i.e. pollination, and moreover, the shelf life of fresh ears is limited to 2-5 days depending on the genotype and storage conditions. On the other hand production of sweet corn for industrial purposes is a very profitable business. The import and export of frozen and prepared or preserved sweet corn are constantly rising in the last decade in Europe (FAOSTAT, 2019), as well as in other parts of the world (Najeeb et al., 2011).

Sweet corn is a very popular vegetable due to its nutritional properties. Its tasty kernels are full of sugars that are in good balance with amino acids, minerals and vitamin $\mathrm{B}$, and it is a good source of fibers. Moreover, sweet corn contains health-promoting phytochemicals such as carotenoids, tocopherols and phenolic acids (Ibrahim and Juvik, 2009; Das and Singh, 2016). Therefore, sweet corn is recognized as quality and delicious food. The content of those phytochemicals is highly influenced by

Original Scientific Paper (Originalni naučni rad)

${ }^{1}$ Srdić J*, Babić V, Kravić N, Snežana Gošić-Dondo S, Maize Research Institute Zemun Polje, Slobodana Bajića 1, Belgrade, Serbia

${ }^{2}$ Milašinović-Šeremešić M, Institute of Food Technology in Novi Sad, Bulevar cara Lazara 1, Novi Sad, Serbia "e-mail: jsrdic@mrizp.rs 
the genotype and also by applied agricultural (Mesarović et al., 2019).

Breeding of sweet corn, like it is in all crops, is devoted to obtaining high and stable yields, but enhancement of technological and sensory properties of the ear and kernel are equally important. Ear yield is the most important trait for producers, but the market and consumers demand good quality traits. In the process of sweet corn breeding, full attention is paid to the uniformity of ear size, length and shape, good kernel row configuration, as well as the kernel properties such as depth, width and color (Pajić, et al., 2010). Fresh ear yield is highly influenced by the genotype, and environmental factors (Srdić et al., 2016). Szymanek et al. (2015) also concluded that the date of the sweet corn harvest is the most important factor that affects sweet corn quality. Nevertheless, differences between genotypes played a significant role in carbohydrates and moisture concentrations that are essential for sweet corn quality.

On the other hand, kernel chemical composition and texture are directly related to the classes of endosperm which is associated to the product acceptance by the consumers (da Silva Camilo et al., 2015). In that study which encompassed 41 panelists who evaluated 6 sweet corn and 2 green corn hybrids, authors concluded that hybrids of sweet corn have greater acceptance than hybrids of green corn regardless of the harvest time. Analyzing consumers' preferences Gere et al. (2014) applied parallel factor analysis (PARAFAC) and Tucker-3 models that included both sensory and instrumental parameters simultaneously. Thereafter they managed to establish age groups of consumers with different preferences according to sweet corn hybrids.

The objective of this study was to establish: a) the effect of genotype and location on the fresh ear yield and yield components such as ear length and a number of kernels per row; b) differences among genotypes considering sensory characteristics, and c) correlation between agronomic and sensory characteristics among sweet corn hybrids.

\section{Material and methods}

This study encompassed a set of 12 sweet corn hybrids, developed at Maize Research Institute Zemun Polje. Three of them are commercial hybrids (ZP504su, ZP355su and ZP347su), and nine are experimental hybrids. Hybrids were sown according to the RCBD in three replicates on two locations (Zemun Polje - nursery field and Zemun Polje - vicinity) in 2018. Each genotype was sown in two rows with the final stand of 40 plants, and the elementary plot was $7 \mathrm{~m}^{2}$, with the sowing density of 57,142 plants ha 1 . Sowing was performed manually on the $16^{\text {th }}$ of April. Harvesting was also done manually in the early morning 24 day after silking, which was between $6^{\text {th }}$ and $12^{\text {th }}$ of July.

Following agronomic traits were analyzed: fresh ear yield $\left(\mathrm{t} \mathrm{ha}^{-1}\right)$, ear length $(\mathrm{cm})$, number of kernels per row, and shelling percentage (\%). Fresh ear yield was measured without husk, from the elementary plot and then calculated to $\mathrm{tha}^{-1}$. Other agronomic traits were analyzed based on a sample of 5 ears. Sensory characteristics were evaluated by 15 voluntary panelists, using $1-9$ point hedonic scale. Score 1 stands for extreme dislike, and it goes up in the sense of likeliness to 5 (neither like nor dislike), to 9 meaning the extreme like. Seven sensory characteristics were analyzed: appearance, color, smell, sweetness, juiciness, crispiness, pericarp hardness, and finally, average scores were drawn from them.

Method of analysis of variance was applied to analyze the results of fresh ear yield and other agronomic traits. Their average scores were compared by the LSD. The correlation between fresh ear yield and the average of sensory characteristics was calculated by the Spearman's correlation coefficient.

\section{Results and discussion}

The results of ANOVA indicate that there is a significant influence of the genotype and location on all observed traits - grain yield, ear length and the number of kernel rows. The interaction of those two factors had a significant impact on grain yield, only (Table 1). On the other hand, the significant influence of genotype and location was not found on the shelling 
percentage (data not shown). The significant influence of the genotype was also observed in previous research (Srdić and Pajić, 2010; Srdić et al., 2016). Kashiani and Saleh 2010, found a strong genetic correlation between husked and dehusked ear yield and some other agronomic trait, i.e. number of kernels per row, plant height, ear diameter, etc. Other research also indicates the significant influence of the genotype on kernel quality (Alan et al., 2014)

Table 1. ANOVA and mean squares for fresh ear yield, ear length and number of kernel rows of the 12 ZP sweet corn hybrids

Tabela 1. ANOVA i sredine kvadrata za prinos svežeg klipa, dužinu klipa i broj redova zrna 12 ZP hibrida kukuruza šé́erca

\begin{tabular}{lrccc}
\hline Sources of variance & d.f. & Fresh ear yield & Ear length & No. of kernel rows \\
\hline Replication & 2 & 1.371 & 1.847 & 0.222 \\
Genotype & 11 & $17.012^{\star *}$ & $9.802^{\star *}$ & $21.995^{\star *}$ \\
Location & 1 & $47.515^{\star *}$ & $45.125^{\star *}$ & $24.500^{\star *}$ \\
G X L & 11 & $3.446^{\star *}$ & 0.216 & 1.833 \\
Error & 46 & 1.163 & 0.340 & 1.729 \\
\hline
\end{tabular}

**, significant at the 0.01 probability level

Average fresh ear yield significantly varied among observed hybrids. The lowest fresh ear yield had commercial hybrid ZP504su (7.14 $\mathrm{t} \mathrm{ha}^{-1}$ ), while the highest yielding was experimental hybrid ZP481/1su - $13.33 \mathrm{t} \mathrm{ha}^{-1}$. The longest ear had hybrid ZP471/1su $(21.3 \mathrm{~cm})$, while its fresh ear yield, on the other hand, was pretty low $\left(9.31 \mathrm{t} \mathrm{ha}^{-1}\right)$. This hybrid with ZP481/1su had the highest average number of kernel rows (20.0). The shortest ear length $(14.3 \mathrm{~cm})$, and the smallest average number of kernel rows (14.3) had the lowest yielding

Table 2. Mean estimates and LSD values of average fresh ear yield, ear length, number of kernel rows and shelling percentage of $12 \mathrm{ZP}$ sweet corn hybrids

Tabela 2. Srednje vrednosti i LSD za prinos svežeg klipa, dužinu klipa i broj redova zrna 12 ZP hibrida kukuruza šećerca

\begin{tabular}{|c|c|c|c|c|}
\hline Hybrid & $\begin{array}{c}\text { Average ear yield } \\
\left(\mathrm{t} \mathrm{ha}^{-1}\right)\end{array}$ & $\begin{array}{l}\text { Ear length } \\
\quad(\mathrm{cm})\end{array}$ & $\begin{array}{l}\text { No. Of kernel } \\
\text { rows }\end{array}$ & $\begin{array}{c}\text { Shelling percentage } \\
(\%)\end{array}$ \\
\hline ZP504su & $7.14 \mathrm{~g}$ & $16.8 \mathrm{~h}$ & $14.3 \mathrm{f}$ & 64.72 \\
\hline ZP355su & $11.92 b c$ & $19.3 \mathrm{de}$ & $16.7 \mathrm{de}$ & 55.04 \\
\hline ZP347su & $10.81 \mathrm{cde}$ & $20.6 \mathrm{ab}$ & $19.0 \mathrm{ab}$ & 56.23 \\
\hline $\mathrm{ZP} 471 / 2 \mathrm{su}$ & $9.31 \mathrm{f}$ & $21.3 \mathrm{a}$ & $20.0 \mathrm{a}$ & 60.40 \\
\hline $\mathrm{ZP} 475 / 2 \mathrm{su}$ & $11.78 \mathrm{bc}$ & $19.8 \mathrm{~cd}$ & $17.7 \mathrm{bcd}$ & 57.20 \\
\hline $\mathrm{ZP} 477 / 2 \mathrm{su}$ & $10.70 \mathrm{def}$ & $18.8 \mathrm{ef}$ & $17.3 \mathrm{~cd}$ & 63.38 \\
\hline ZP481/1su & $13.33 \mathrm{a}$ & $19.5 \mathrm{~cd}$ & $20.0 \mathrm{a}$ & 59.72 \\
\hline $\mathrm{ZP} 482 / 1 \mathrm{su}$ & $11.05 \mathrm{~cd}$ & $17.5 \mathrm{gh}$ & $16.7 \mathrm{de}$ & 63.30 \\
\hline ZP483/1su & $12.39 \mathrm{ef}$ & $19.2 \mathrm{de}$ & $18.0 \mathrm{bcd}$ & 67.12 \\
\hline $\mathrm{ZP} 484 / 1 \mathrm{su}$ & $12.53 \mathrm{ab}$ & $20.2 b c$ & $15.3 \mathrm{ef}$ & 65.38 \\
\hline ZP485/1su & $10.12 \mathrm{cde}$ & $18.8 \mathrm{ef}$ & $14.7 \mathrm{f}$ & 63.16 \\
\hline ZP486/1su & $11.64 \mathrm{ab}$ & $18.2 \mathrm{fg}$ & $18.7 \mathrm{abc}$ & 65.36 \\
\hline $\operatorname{LSD}_{0.05}$ & 1.25 & 0.68 & 1.53 & \\
\hline
\end{tabular}

Means followed by the same letter are not significantly different according to the LSD0.05 
hybrid ZP504su (Table 2). Shelling percentage presents the ratio between the fresh kernel weight and the weight of the fresh ear without husk. Analysis of variance did not show significant differences among examined hybrids and locations, so it was not presented in this paper, and for that reason, LSD was not performed. In Table 2 . are only presented the average scores of the shelling percentage for the given hybrids, and they ranged from $55.04 \%$ (ZP355su) to $67.12 \%$ (ZP483/1su).

Differences between sensory characteristics among hybrids included in this experiment were noticed, although all hybrids had satisfactory sensory characteristics with the average sensory mark above 7.30/9.00. Significant differences among genotypes concerning sensory characteristics were also found in da Silva Camilo et al. (2015). The best sweet corn hybrid according to the average sensory mark was ZP483/1su (8.29/9.00). This hybrid also had very high average fresh ear yield (12.39 $\left.\mathrm{t} \mathrm{ha}^{-1}\right)$ and was third according to the average fresh ear yield. On the other hand, the highest yielding hybrid ZP481/1su had lower marks of sensory characteristics (7.70/9.00). Due to the fact that consumers mostly pay attention to the sensory characteristics of sweet corn, this could reflect badly on this particular hybrid and its commercialization. Hybrid ZP504su, which had the lowest agronomic characteristics, also had the lowest average sensory mark (7.33/9.00). Interestingly, some of the hybrids like ZP483/1su and ZP355su possess both good agronomic and sensory characteristics, because they were highly ranked according to both of them.

Some hybrids had the same (ZP504su) or very similar (ZP355su, ZP475/2su, ZP477/2su, and $\mathrm{ZP} 486 / 1 \mathrm{su}$ ) rankings according to the average fresh ear yield and average sensory marks. Nevertheless, no significant correlation could be established according to the Spearman's correlation coefficient $(r=0.31)$, which was low and not significant. Low correlation was also found among agronomic and sensory characteristics of popcorn (Srdić et al., 2017). In that research, it was found that the highest yielding hybrids, or with highest popping volume didn't possess the most attractive sensory characteristics. Moreover, yielding potential and popping volume are mostly in reverse correlation.

Such results indicate that the breeding process of sweet corn is highly demanding. The yield itself is very important but not the only important trait of interest in sweet corn breeding. On the other hand, there is genetic variability in the observed genetic material that could provide, by the various breeding methods, an enhancement in the terms of both agronomic and sensory characteristics.

Table 3. Mean estimates of sensory characteristics of 12 ZP sweet corn hybrids

Tabela 3. Srednje vrednosti senzornih karakteristika 12 ZP hibrida kukuruza šećerca

\begin{tabular}{lcccccccc}
\hline \multicolumn{1}{c}{ Hybrid } & Appearance & Color & Smell & Sweetness & Juiciness & Crispiness & $\begin{array}{c}\text { Pericarp } \\
\text { hardness }\end{array}$ & Average \\
\hline ZP504su & 6.93 & 8.07 & 7.33 & 7.40 & 7.07 & 7.33 & 7.20 & 7.33 \\
ZP355su & 7.87 & 7.53 & 7.60 & 8.20 & 8.47 & 8.13 & 8.33 & 8.02 \\
ZP347su & 8.47 & 8.20 & 7.80 & 7.80 & 7.87 & 8.27 & 8.07 & 8.07 \\
ZP471/2su & 7.40 & 7.87 & 7.87 & 7.20 & 7.73 & 8.13 & 7.73 & 7.70 \\
ZP475/2su & 8.33 & 8.33 & 7.87 & 7.87 & 7.80 & 7.87 & 7.00 & 7.87 \\
ZP477/2su & 7.20 & 7.60 & 7.87 & 7.53 & 7.73 & 7.67 & 7.67 & 7.61 \\
ZP481/1su & 7.87 & 7.87 & 8.00 & 7.47 & 7.67 & 7.53 & 7.53 & 7.70 \\
ZP482/1su & 7.40 & 7.53 & 7.80 & 7.80 & 8.20 & 8.13 & 8.20 & 7.87 \\
ZP483/1su & 8.87 & 8.67 & 8.33 & 8.00 & 8.20 & 7.93 & 8.00 & 8.29 \\
ZP484/1su & 7.13 & 7.53 & 7.53 & 7.53 & 7.47 & 7.60 & 7.20 & 7.43 \\
ZP485/1su & 7.67 & 8.07 & 8.07 & 8.07 & 7.67 & 7.67 & 7.53 & 7.82 \\
ZP486/1su & 8.27 & 8.53 & 8.07 & 7.27 & 7.47 & 7.40 & 7.20 & 7.74 \\
\hline
\end{tabular}




\section{Conclusion}

Results obtained in this research underline the challenging process of sweet corn hybrids breeding, due to the necessity of obtaining high yielding and quality hybrids. Those traits are mainly in low correlation, but of equal importance, therefore through the breeding process, both of those characteristics need to be improved.

Hybrid with the highest yielding potential ZP481/1su (13.33 t ha-1), obtained low average sensory mark (7.70/9.00). The lowest average sensory mark (7.33/9.00) had the lowest yielding hybrid ZP504su. Hybrids with high average fresh ear yield and high sensory marks were ZP355su and $\mathrm{ZP} 483 / 1$ su, indicating those two as perspective hybrids for further commercialization.

\section{Acknowledgement}

This paper is a result of the research within the Project TR 31068, supported by the Ministry of Education, Science and Technological Development of the Republic of Serbia.

\section{References}

Alan O, Kinaci G, Kinaci E, Budak Bascifitci Z, Sonmez K, Evrenosoglu Y, Kutlu I (2014): Kernel quality of some sweet corn varieties in relationship to processing. Not. Bot. Horti. Agrobo., 42(2): 414-419.

Das AK, Singh V (2016): Antioxidative free and bound phenolic constituents in botanical fractions of Indian speciality maize (Zea mays L.) genotypes. Food Chem., 201: 298-306.

FAOSTAT (2019), Food and agriculture organization of the United Nations, statistics division. http://www.fao.org/faostat/en/\#data/TP

Gere A, Loso V, Györey A, Kovacs S, Huzsvai L, Nabradi A, Kokai Z, Sipos L (2014): Applying parallel factor analysis and Tucker-3 methods on sensory and instrumental data to establish preference maps: a case study on sweet corn varieties. Science of Food and Agriculture, 94(15): 3213-3225

Ibrahim KE, Juvik JA (2009): Feasibility for improving phytonutrient content in vegetable crops using conventional breeding strategies: a case study with carotenoids and tocopherols in sweet corn and broccoli. J. Agric. Food Chem., 57: 4636-4644.

Kashiani P, Saleh G (2010): Estimation of genetic correlations on sweet corn inbred lines using SAS mixed model. American Journal of Agriculture and Biological Sciences, 5(3): 309-314.

Mesarović J, Srdić J, Mladenović Drinić S, Dragičević V, Simić M, Brankov M, Milojković-Opsenica D (2019): Evaluation of the nutritional profile of sweet maize after herbicide and foliar fertilizer application. Journal of Cereal Science, 87: 132-137.

Najeeb S, Sheikh FA, Ahangar MA, Tel NA (2011): Popularization of sweet corn (Zea mays L. saccharata) under temperate conditions to boost the socioeconomic conditions. Maize Genetics Cooperation Newsletter, 85, https://mnl.maizegdb.org/85/ PDF/04najeeb.pdf.

Pajić Z, Radosavljević M, Filipović M, Todorović G, Srdić J, Pavlov M (2010): Breeding of speciality maize for industrial purposes. Genetika, 42: 57-66.

da Silva Camilo J, Barbieri Barbosa VH, Rangel RM, Bonnas DS, Luz JMQ, Oliveira RC (2015): Sensory acceptance of hybrids of sweet corn and hybrids of green corn in harvest intervals. Revista Ceres, 62(1): 01-08.

Szymanek M, Tanas W, Kassar FH (2015): Kernel carbohydrates concentration in sugary-1, sugary enhanced and shrunken sweet corn kernels. Agriculture and Agricultural Science Procedia, 7: 260-264.

Srdić J, Pajić Z, (2010): Nasleđivanje i korelacija prinosa klipa i randmana zrna kod kukuruza šećerca (Zea mays L. saccharata). Journal of Scientific Agricultural Research, 71:39-45.

Srdić J, Pajić Z, Filipović M (2016): Sweet corn (Zea mays L.) fresh ear yield in dependence of genotype and the environment. Selekcija i semenarstvo, 22: 27-33.

Srdić J, Milašinović-Šeremešić M, Radosavljević M, Kravić N, Babić V (2017): Evaluation of agronomic and sensory characteristics of the popcorn kernel. Journal on Processing and Energy in Agriculture, 21(4):185-187. 


\title{
PROCENA AGRONOMSKIH I SENZORNIH KARAKTERISTIKA HIBRIDA KUKURUZA ŠEĆERCA
}

\author{
Jelena Srdić, Marija Milašinović-Šeremešić, Vojka Babić, Natalija Kravić, \\ Snežana Gošić-Dondo
}

\begin{abstract}
Sažetak
Kukuruz šećerac se smatra ukusnim i kvalitetnim povrćem. Njegovo zrno sadrži šećere, amino-kiseline, minerale i vitamin B koji su u veoma dobrom odnosu. Koristi se u svežem stanju odmah nakon berbe, ali takođe i za industrijsku preradu i zamrzavanje zrna. U procesu oplemenjivanja kukuruza šećerca, podjednaka pažnja posvećuje se stvaranju hibrida visokog i stabilnog prinosa, kao i poboljšanju tehnoloških i senzornih karakteristika klipa i zrna. Cilj ovog istraživanja bio je da se utvrde agronomske i senzorne karakteristike 12 hibrida kukuruza šećerca, od kojih su tri hibrida bila komercijalna, a 9 eksperimentalnih. Ogled je bio postavljen po principu RCBD, na dve lokacije i u tri ponavljanja. Analiza agronomskih karakteristika obuhvatila je: prinos svežeg klipa bez komušine, dužinu klipa, broj redova zrna i randman zrna. Od senzornih karakteristika analizirane su sledeće: izgled klipa, boja, miris, slatkoća, sočnost, hrskavost i tvrdoća perikarpa. Senzorne karakteristike procenjivalo je 15 dobrovoljaca, koristeći skalu 1 - 9 . Prinos svežeg klipa značajno je varirao u odnosu na lokacije i hibride. Najviši prinos postigao je eksperimentalni hibrid ZP 481/1su - 13,33 t ha ${ }^{-1}$, dok je najniži prinos bio kod hibrida ZP504su $\left(7,14 \mathrm{t} \mathrm{ha}^{-1}\right)$. Razlike u pogledu senzornih karakteristika između posmatranih hibrida takođe su primećene, ali svi hibridi su uglavnom imali zadovoljavajuće senzorne ocene sa srednjom vrednošću preko 7,30/9,00. Najbolji hibrid kukuruza šećerca prema senzornim ocenama bio je ZP 483/1su (8.29/9,00), dok je najprinosniji hibrid ZP 481/1su imao nisku senzornu ocenu od 7,70.
\end{abstract}

Ključne reči: kukuruz šećerac, prinos svežeg klipa, senzorne karakteristike

Primljen: 15.11.2019.

Prihvaćen: 29.11.2019. 